The blood supply to the scaphoid consists of three main groups of vessels, the laterovolar, dorsal and the distal (Taleisnik \& Kelly, 1966). These vessels originate at separate levels from the radial artery or from the radial artery and its superficial palmar branch, and after a short trajectory penetrate the scaphoid at the level of the waist and the tubercle. This arrangement of blood vessels, plus the fact that the scaphoid normally enjoys a considerable range of movement, probably explains the absence of apparent damage to the blood supply of the scaphoid, following its dislocation and closed reduction.

\section{Conclusion}

Two cases of traumatic dislocation of the scaphoid are described. In both cases closed reduction was carried out with success within a few hours of injury. In both cases full function was rapidly restored with no evidence of avascular change. If, as in some reported cases, there is delayed diagnosis, closed manipulation may not be successful, and operative reduction has to be carried out. Some of these cases were complicated by avascular changes in the scaphoid.

\section{Acknowledgment}

I would like to thank Mr G. P. Arden for permission to publish these cases and for his helpful criticism.

\section{References}

BuzBy, B.F. (1934) Isolated radial dislocation of the carpal scaphoid. Ann. Surg. 100, 553.

Connell, M.C. \& Dyson, R.P. (1955) Dislocation of the carpal scaphoid. J. Bone Jt Surg. 27B, 252.

Higgs, S.L. (1930) Two cases of dislocation of the carpal scaphoid. Proc. roy. Soc. Med. 23, 1337.

KUTH, J.R. (1939) Isolated dislocation of the carpal scaphoid. J. Bone Jt Surg. 21, 479.

Russell, T.B. (1949) Intercarpal dislocations and fracture dislocations. J. Bone Jt Surg. 31B, 524.

Schlossbach, T. (1954) Dislocation of carpal navicular bone not associated with fracture. J. med. Soc. New Jersey, 51, 533.

Taleisnik, J. \& Kelly, P.J. (1966) The extraosseous and interosseous blood supply of the scaphoid bone. J. Bcre Jt Surg. 48A, 1125.

Thompson, T.C., CAmpbell, R.D. \& ARNold, W.D. (1964) Primary and secondary dislocation of the scaphoid bone. $J$. Bone Jt Surg. 46B, 73.

WoODD-WALKER, G.B. (1943) Dislocation of carpal navicular. Brit. J. Surg. 30, 380.

\title{
Renal agenesis, oligohydramnios and diabetes mellitus
}

\author{
A. R. AdAmSON \\ M.B., M.R.C.P. \\ Senior Registrar, \\ St Mary's Hospital, London, W.2
}

THE ASSOCIATION of foetal renal agenesis and oligohydramnios is well recognized. At least 250 cases of renal agenesis have now been reported and in the majority there seems to have been a deficiency or absence of liquor (Bardram, 1930; Bates, 1933; Weber \& Israel, 1958; Bain \& Scott, 1960; Potter, 1965).

An association with maternal diabetes mellitus is not mentioned in these reports. Two such cases are, therefore, considered worth reporting.

\section{Case 1}

The mother, a 24-year-old English woman, has been a known diabetic since the age of 7 . After trying to conceive for 5 years her first pregnancy in 1965 resulted in a fresh stillbirth, weight $10 \mathrm{lb} 5 \mathrm{oz}$ at 38

\footnotetext{
* Present address: Department of Obstetrics, Royal University of Malta.
}

\author{
B. BENSTER* \\ M.B., Ch.B., M.R.C.O.G. \\ Registrar, \\ Canadian Red Cross Memorial Hospital, Taplow, Berks
}

weeks' gestation. At post mortem no congenital abnormalities were detected.

She was first seen at the Canadian Red Cross Hospital on the 7 September 1966 in the 14th week of her second pregnancy. During early pregnancy her diabetic control seems to have been satisfactory with an insulin requirement of 24 units of soluble insulin plus 8 units NPH in the morning and 20 units soluble insulin plus 8 units NPH in the evening.

Throughout the ante-natal period it was noted that the uterus was persistently small for the period of gestation. Foetal movements were first felt at 23 weeks by dates, 20 weeks by size. From the 28th week there was mild elevation of blood pressure, reaching a maximum of $140 / 90 \mathrm{mmHg}$ at 32 weeks. The insulin requirement gradually increased and by the 34th week she was having 32 units of soluble 
insulin, plus $12 \mathrm{NPH}$ in the morning and 24 units soluble insulin, plus $12 \mathrm{NPH}$ in the evening.

On the 1 February 1967 at $35 \frac{1}{2}$ weeks by dates labour began spontaneously. The first stage lasted for $6 \mathrm{hr}$ and after $20 \mathrm{~min}$ in the second stage she had an easy spontaneous vaginal delivery of a live female infant, birth weight $5 \mathrm{lb} 9 \mathrm{oz}$. The placenta weighed $1 \mathrm{lb} 3 \mathrm{oz}$ and looked healthy. The interesting feature about the labour was that no liquor was seen at any time and in retrospect this might explain why she had been persistently small for her dates.

The infant's condition at birth was poor, the Apgar score was 2 after $60 \mathrm{sec}, 2$ after $3 \mathrm{~min}, 5$ after $5 \mathrm{~min}$ and 5 after $10 \mathrm{~min}$. The cord blood sugar was $103 \mathrm{mg} / 100 \mathrm{ml}$. There was an initial response to mucus extraction and intermittent positive pressure oxygen. After $4 \mathrm{hr}$ the infant was still having apnoeic attacks and the blood sugar fell to $17 \mathrm{mg} / 100 \mathrm{ml}$. An intravenous dextrose drip was commenced. The infant's condition continued to deteriorate and death occurred after $7 \mathrm{hr}$. During this time neither urine nor meconium had been passed.

\section{Necropsy (Dr F. E. Scott)}

A slightly premature female infant, length $47 \mathrm{~cm}$, weight $2545 \mathrm{~g}$. There were no external signs of congenital defect. There were no kidneys or ureters present. The bladder was very small but a lumen was demonstrable. The uterus, tubes and ovaries were normal.

The left lung was totally unexpanded, weight $13 \mathrm{~g}$. The right lung showed expansion only of the anterior fringe of the upper lobe, weight $15 \mathrm{~g}$. The heart was of normal size, weight $22 \mathrm{~g}$. There was a high ventricular septal defect about $3 \mathrm{~mm}$ in diameter. The suprarenal glands were of flattened ovoid shape, combined weight $13 \mathrm{~g}$.

All other organs were normal.

\section{Case 2}

The mother, a 41-year-old midwife from West Africa, was referred to the Antenatal booking clinic at St Mary's Hospital on 1 March 1966, in the 11th week of her second pregnancy. In her first pregnancy in 1953 she had had a normal delivery of a live infant birth weight $6 \mathrm{lb} 13 \mathrm{oz}$. There was no other significant past history and no family history of diabetes. She was found to have a hypochromic anaemia ( $\mathrm{Hb} 10.7 \mathrm{~g})$ with sickle-cell trait and $0.25 \%$ sugar in the urine. At the next two ante-natal visits the urine was normal but at 27 weeks glycosuria was again noted and a glucose tolerance test was performed. This was diabetic in type-fasting capillary blood sugar $125 \mathrm{mg} / 100 \mathrm{ml}$; after $50 \mathrm{~g}$ glucose by mouth the blood sugar levels were:

$30 \mathrm{~min}, 205 \mathrm{mg} / 100 \mathrm{ml}$; $60 \mathrm{~min}, 240 \mathrm{mg} / 100 \mathrm{ml}$; $90 \mathrm{~min}, 190 \mathrm{mg} / 100 \mathrm{ml} ; 120 \mathrm{~min}, 140 \mathrm{mg} / 100 \mathrm{ml}$.
She was referred to the diabetic clinic and treatment was started with a 1000 calorie diet which was continued until delivery. For 2 weeks she was given chlorpropamide $100 \mathrm{mg}$ daily but this was found to be unnecessary. Her diabetes was well controlled throughout the pregnancy with random blood sugars between 80 and $120 \mathrm{mg} / 100 \mathrm{ml}$. Foetal movements were felt at 20 weeks. When she was admitted at 37 weeks it was noted that the baby did not appear to have grown since the previous visit and was small in size. She was induced at 38 weeks and at artificial rupture of the membranes no liquor was seen. Labour began $12 \mathrm{hr}$ after induction. The foetal heart was difficult to hear, but when heard was reported as normal. After a first stage lasting $8 \mathrm{hr}$ she had a spontaneous vaginal delivery of a fresh still-born female infant. No liquor was seen at any time. The puerperium was normal and 2 months after delivery a repeat glucose tolerance test was normal.

\section{Necropsy (Dr G. N. Smith)}

A small well formed female infant. Body weight $1950 \mathrm{~g}$, length $44 \mathrm{~cm}$, placental weight $375 \mathrm{~g}$.

There were no external signs of congenital defect. No renal tissue was detected. The bladder was normal and the ureters ended blindly at the pelvic brim. The uterus, tubes, ovaries, vagina and external genitalia were all normal. The adrenals were slightlye enlarged, combined weight $14 \mathrm{~g}$ and in a lower position than normal. The lungs were atelectatic. All other organs were normal.

\section{Discussion}

The interesting feature of these cases is the association of renal agenesis and oligohydramnios with maternal diabetes. An increased incidence of congenital malformation in newborn infants of diabetic women has been reported frequently (Lecorché, 1885; White, 1949; Koller, 1953; Hagbard, 1956; Driscoll, Benirschke \& Curtis, 1960; Pedersen, Tygstrup \& Pedersen, 1964). There is no characteristic congenital abnormality associated with maternal diabetes but an increased incidence of limb and spine abnormalities has been suggested (Pedersen et al., 1964; Kucera, Lenz \& Maier, 1965). Congenital abnormalities are thought to occur more commonly in the infants of those women who have had diabetes for more than 10 years and who have vascular complications (Koller, 1953; Pedersen et al., 1964). Neither of our patients has clinical evidence of vascular complications although Case 1 has had diabetes for 17 years. The only reported cases of renal agenesis in the infants of diabetic mothers have been associated with severe limb and spine abnormalities (Driscoll et al., 1960; Kucera et al., 1965). Potter (1965) in her series of fifty cases reports no associations with maternal diabetes. 
Another point to consider is whether treatment of diabetes could have played a significant part in the aetiology of renal agenesis. The critical time for renal development is between 3 and 7 weeks, the somite stage to $18 \mathrm{~mm}$ size. During this time the mesonephros, mesonephric duct, metanephros and ureteric bud are in an active stage of development (Shikinami, 1926; Torrey, 1954). Hypoglycaemia has been suggested as the cause of congenital malformations (Hagbard, 1956; Kyle, 1963). In these cases there was no evidence of hypoglycaemia during the critical period. Oral hypoglycaemic drugs have been reported to be teratogenic (Larssen \& Sterky, 1960). Although the second patient was given chlorpropamide for 2 weeks, this was not until after the critical period for renal development.

The circulation of amniotic fluid probably involves several pathways (Plentyl, 1966). The association of oligohydramnios with renal agenesis suggests that the foetal urinary system is an important pathway for maintaining normal amniotic fluid volume.

\section{Acknowledgments}

We should like to thank Dr J. Lister, Mr H. J. Malkin, Dr C. A. Young and Professor P. J. Huntingford for permission to describe these cases.

\section{References}

Bain, A.D. \& ScotT, J.S. (1960) Renal agenesis and severe urinary tract dysplasia. Brit. med. J. 1, 841.

Bardram, E.L. (1930) Congenital kidney malformations and oligohydramnios. Acta Obstet. Gynec. Scand. 10, 134.
BAtes, G.S. (1933) Bilateral renal agenesis in the foetus associated with oligohydramnios. Amer. J. Obstet. Gynec. 25, 41.

Driscoll, S.G., Benirschke, K. \& Curtis, G.W. (1960) Neonatal deaths among infants of diabetic mothers. Amer. J. Dis. Child. 100, 818.

Hagbard, L. (1956) Pregnancy and diabetes mellitus. Acta Obstet. Gynec. Scand. 35, Suppl. 1.

Koller, O. (1953) Diabetes and pregnancy. Acta Obstet. Gynec. Scand. 32, 80.

Kucera, J., Lenz, W. \& MAIER, W. (1965) Missbildungen der Beine und der Kaudalen Wirbezsäule Bei Kindern Diabetischer Mütter. Dtsch, med. Wschr. 90, 901.

KYLE, G.C. (1963) Diabetes and pregnancy. Ann. intern. Med. 59, Suppl. 3, 35.

Larssen, Y. \& Sterky, G. (1960) Possible teratogenic effect of tolbutamide in a pregnant prediabetic. Lancet, ii, 1424.

LeCORCHE, E. (1885) Du diabete: dans ses rapports avec la vie uterine, la menstruation et la grossesse. Ann. Gynec. Obstet. 24, 257.

Pedersen, L., Tygstrup, I. \& Pedersen, J. (1964) Congenital malformations in newborn infants of diabetic women. Lancet, i, 1124.

Plentyl, A.A. (1966) Formation and circulation of amniotic fluid. Clin. Obstet. Gynec. 9, 427.

PotTER, E.L. (1965) Bilateral absence of ureters and kidneys. Obstet. Gynec. 25, 3.

ShIKINAMI, J. (1926) Detailed form of the Wolffian body in human embryos of the first eight weeks. Contrib. Embryol. Carnegie Inst. Wash. 18, 49.

TORREY, T.W. (1954) The early development of the human nephros. Contrib. Embryol. Carnegie Inst. Wash. 35, 177.

WebER, L.L. \& ISRAEL, S.C. (1958) Renal agenesis and oligohydramnios. Obstet. Gynec. 12, 575.

White, P. (1949) Pregnancy complicating diabetes. Amer. J. Med. 7, 609.

\title{
Alcoholic lymphalgia in early syphilis
}

\author{
D. J. M. WRIGHT \\ M.B., B.S. \\ Registrar, \\ Department of Venereology, King's College \\ Hospital, London, S.E.5
}

PaIN in the cervical and inguinal lymph nodes following ingestion of alcohol is described in a patient with early syphilis.

\section{Case report}

A 35-year-old Jamaican serviceman gave a history of having had a penile sore 4 months before which had healed without leaving a scar. Subsequently, while on service abroad, his inguinal lymph glands enlarged, were punctured and, on dark-ground examination, disclosed $T$. pallidum. Serological tests for syphilis were positive at that time. He was then treated with ten injections of 'penicillin', having an acute febrile (? Herxheimer) reaction following the initial injection.

He now attended complaining that he had been forced to give up drinking alcohol for 1 month, as, each time he drank, a severe pain developed in his inguinal and cervical lymph nodes. During this period, he lost 1 stone in weight. The pain had a 